\title{
Refuge
}

Canada's Journal on Refugees

Revue canadienne sur les réfugiés

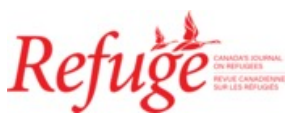

\section{(Mis)trusted Contact: Resettlement Knowledge Assets and the Third Space of Refugee Reception}

\author{
Christopher Kyriakides, Arthur McLuhan, Karen Anderson, Lubna Bajjali and \\ Noheir Elgendy
}

Volume 35, Number 2, 2019

Private Sponsorship in Canada

URI: https://id.erudit.org/iderudit/1064817ar

DOI: https://doi.org/10.7202/1064817ar

See table of contents

Publisher(s)

Centre for Refugee Studies, York University

ISSN

0229-5113 (print)

1920-7336 (digital)

Explore this journal

Cite this article

Kyriakides, C., McLuhan, A., Anderson, K., Bajjali, L. \& Elgendy, N. (2019). (Mis)trusted Contact: Resettlement Knowledge Assets and the Third Space of Refugee Reception. Refuge, 35(2), 24-35. https://doi.org/10.7202/1064817ar

\section{Article abstract}

Drawing on interviews with 204 participants in two studies of privately sponsored refugee resettlement in Ontario, Canada, we explore the resettlement effects of pre-arrival contact on the interactional dynamics between private sponsors and privately sponsored Syrian refugees. Those who had regular pre-arrival contact via digital applications such as Facebook, Skype, and Whatsapp reported more positive, "successful" resettlement experiences than those who had not. This pre-arrival interactive dynamic has theoretical/conceptual implications beyond an understanding of the benefits of "information exchange." Pre-arrival sponsor-sponsored interaction is not bound by the contexts of displacement or resettlement, but constitutes a "third space” of reception, co-created through trusted contact. We develop the concept of "resettlement knowledge assets" and report on how these assets emerge through pre-arrival trust building, modify the resettlement expectations of both sponsors and sponsored, and reduce resettlement uncertainty.
Copyright (c) Refuge: Canada's Journal on Refugees, 2019

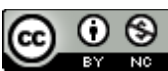

This document is protected by copyright law. Use of the services of Érudit (including reproduction) is subject to its terms and conditions, which can be viewed online.

https://apropos.erudit.org/en/users/policy-on-use/ 


\title{
(Mis)Trusted Contact: \\ Resettlement Knowledge Assets and the Third Space of Refugee Reception
}

\author{
CHRISTOPHER KYRIAKIDES, ARTHUR MCLUHAN, KAREN ANDERSON, \\ LUBNA BAJJALI, and NOHEIR ELGENDY
}

\section{Abstract}

Drawing on interviews with 204 participants in two studies of privately sponsored refugee resettlement in Ontario, Canada, we explore the resettlement effects of pre-arrival contact on the interactional dynamics between private sponsors and privately sponsored Syrian refugees. Those who had regular pre-arrival contact via digital applications such as Facebook, Skype, and Whatsapp reported more positive, "successful" resettlement experiences than those who had not. This pre-arrival interactive dynamic has theoretical/conceptual implications beyond an understanding of the benefits of "information exchange." Pre-arrival sponsor-sponsored interaction is not bound by the contexts of displacement or resettlement, but constitutes a "third space" of reception, co-created through trusted contact. We develop the concept of "resettlement knowledge assets" and report on how these assets emerge through pre-arrival trust building, modify the resettlement expectations of both sponsors and sponsored, and reduce resettlement uncertainty.

\section{Résumé}

À partir déntrevues avec 204 participants à deux études sur la réinstallation de réfugiés parrainée de façon privée en Ontario, Canada, nous explorons les effet sur la réinstallation que les contacts avant l'arrivée ont sur la dynamique interactionnelle entre les parrains privés et les réfugiés parrainés de façon privée. Ceux qui ont entretenu des contacts réguliers avant l'arrivée à travers des applications digitales telles que Facebook, Skype et Whatsapp ont rapporté des expériences de réinstallation plus positives et réussies que ceux qui nien ont pas eu. Cette dynamique interactive avant l'arrivée a des implications théoriques et conceptuelles audelà d'une compréhension des bénéfices de léchange d'information. L'interaction avant l'arrivée entre les parrains et les parrainés nest pas limitée aux contextes de déplacement et de réinstallation, mais constitue un espace tiers de réception, co-créé à travers un rapport de confiance. Nous développons le concept d'atouts de connaissance liées à la réinstallation et rapportons comment ces atouts émergent à travers le (c) C. Kyriakides, A. McLuhan, K. Anderson, L. Bajjali, and N. Elgendy, 2019. This open-access work is licensed under a Creative Commons Attribution-NonCommercial 4.0 International Licence, which permits use, reproduction, and distribution in any medium for non-commercial purposes, provided the original authorship is credited and the original publication in Refuge: Canada's Journal on Refugees is cited.
Cette œuvre en libre accès fait l'objet d'une licence Creative Commons AttributionNonCommercial 4.o International License, laquelle autorise l'utilisation, la reproduction et la distribution de l’œuvre sur tout support à des fins non commerciales, pourvu que l'auteur ou les auteurs originaux soient mentionnés et que la publication originale dans Refuge: revue canadienne sur les réfugiés soit citée. 
développement d'un rapport de confiance avant l'arrivée, modifient les attentes liées à la réinstallation des parrains et des parrainés, et réduisent l'incertitude de la réinstallation.

\section{Introduction}

7 his article reports on findings from two studies that examined the inclusion and exclusion of privately sponsored Syrian refugees in Ontario, Canada. In late 2016 and early 2017, we carried out a qualitative study of the Canadian Private Sponsorship of Refugees Program in the rural reception context of Northumberland County. We interviewed 109 participants from private sponsor groups, public agencies, and privately sponsored Syrian refugees during their first twelve months of resettlement. Our follow-up urban comparative study in late 2017 and early 2018 included ninety-five participants from private sponsor groups and privately sponsored Syrian refugees in the Greater Toronto Area, some of whom had completed their twelve months of sponsored resettlement. An unexpected finding emerged from the first study: those who had engaged in regular prearrival contact via digital applications such as Facebook, Skype, and Whatsapp reported more positive, "successful" resettlement experiences than those who had not. Our followup comparative study confirmed our original findings.

In this article we report on, and offer an analysis of, the findings from both studies. In analyzing the effects of prearrival, digitally supported, sponsor-sponsored contact on refugees' subjective experiences of resettlement success, we turned to Mollering's tripartite theory of trust-building, Horst and Grabska's work on uncertainty and refugeeness, and Sharratt and Usoro's observations on the role of trust in distinguishing between information and knowledge. Their work helped us to develop two concepts: the "digital third space of refugee reception" and "resettlement knowledge assets." We demonstrate that when pre-arrival, sponsorsponsored exchanges occur in co-created, digital "third spaces of reception," trust can flourish and information can become "resettlement knowledge assets" that modify the resettlement expectations of both sponsors and sponsored, reduce resettlement uncertainty, and enhance subjective experiences of resettlement success.

\section{Trust, Refuge, and Communication}

The study of trust is a key area of social scientific enquiry. ${ }^{1}$ Trust generally exhibits situational characteristics in which two or more parties engage in a mutually accepted relationship where the future outcomes of their transactions are unknown. The uncertainty of future outcomes connotes the degree of risk associated with the condition of reliance between the parties involved. As a potential influence on, and outcome of, individual interaction, social group engagement, and as a generalized state of a given society, trust is an asset.

National citizens who place greater trust in one another have more efficient public institutions and experience higher rates of economic growth. ${ }^{2}$ Trust is involved in starting a business and performing voluntary work. ${ }^{3}$ Trusting individuals are healthier and happier. ${ }^{4}$ Ljunije has demonstrated that the "inherited trust" of second-generation immigrants is positively correlated with economic and educational success, significant even after controlling for additional firstgeneration influences such as income per capita and institutions. ${ }^{5}$ Trust has profound implications for understanding forced migration and is fundamental to the experiences of refugees. ${ }^{6}$ The dissolution and restoration of trust lies at the core of conflict-induced displacement.7 While a "trust deficit" cannot be generalized to all refugees, a shortage of social trust is embedded in the experience of conflict-induced displacement. ${ }^{8}$

Recent work draws attention to the trust involved in refugee institution interactions; 9 the relationship between the sociocultural context of countries of origin and the degree of social trust in exile; ${ }^{10}$ the role of displacement/conflict events in establishing fear and trust in exile; ${ }^{11}$ and the effect of conflict-induced trauma on refugees' social trust, sense of belonging, and community integration in exile. ${ }^{12}$ Hynes's study of asylum seekers in England notes that refugees "mistrust and are mistrusted at many levels in both industrialized and developing countries," and that once lost, trust is difficult to restore. ${ }^{13}$ Of the four forms of trust-social, political, institutional and restorative - that Hynes identifies, restorative trust- "the process by which an individual regains social, political, or institutional trust"-is particularly difficult to achieve. ${ }^{14}$ There are important considerations related to trust with respect to differences between refugees and migrants and their descendants. In both cases, third-country resettlement often entails entry into host cultures of mistrust. ${ }^{15}$ But, especially in the case of refugees who flee conflict, mistrust is often an appropriate response that can enhance the feeling of security. ${ }^{16}$

While there is an informative body of academic research on private sponsorship, ${ }^{17}$ there is a significant lack of in-depth work on how the complexity of sponsor-sponsored interaction-especially with regard to restorative trust-might positively or negatively affect resettlement. The Canadian Private Sponsorship of Refugees Program (PSRP) provides a unique opportunity to investigate the dynamic of trust/mistrust in refugee-host relations. PSRP formalizes a state-sanctioned "private" relationship between "sponsors" and "sponsored" who interact regularly during the first twelve months of resettlement. Sponsor group "hosts" are expected to help 
sponsored "refugees" attain self-sufficiency within one year of sponsorship. Both refugee and host are placed in direct, formalized, interactive relationships. In the refugee-host dynamic of PSRP-initiated resettlement, citizen hosts have not been party to the initial trust-eroding conflict that refugees experience. The refugee-host relationship is not reconciliatory in the strict definition adhered to by scholars of conflictresolution. Nevertheless, it is a relationship in which one party (arguably) has greater power than the other. Given that trust entails cooperation, ${ }^{18}$ the power dynamic occasioned by the charitable responses of Canadians with full citizenship rights towards non-citizen refugees has the potential to undermine or even erode restorative trust. The interactive sponsor-sponsored relationship therefore offers a micro-level lens into the dynamic of trust-building in refugee-host relations.

Mollering's tripartite theory of trust-building, including interpretation, expectation, and suspension, is instructive. ${ }^{19}$ Expectation is derived from a combination of interpretation and the suspension of the unknowable: "Bracketing the unknowable" makes "interpretative knowledge momentarily knowable." ${ }^{20}$ A trust-control duality is important in drawing out how the contingency of future outcomes, which can lead to a state of dependency between unequal actors, is countered by trust. ${ }^{21}$ Mollering's theory resonates with sponsorsponsored pre-arrival communication in three ways. First, "uncertainty" is a basic feature of displacement and exile. As Horst and Grabska note, "Uncertainty, in its meaning of imperfect knowledge and the unpredictability of the future, is central to studies that theorize conflict-induced displacement, transit, and refugeeness." 22 Uncertainty related to the unknowable outcome of future events conveys precarity, but in relation to resettlement it also suggests the impossibility of knowing where one will end up. What are the socio-cultural conditions, economic opportunities, and political climate of reception? What characteristics, beliefs, and attitudes do sponsors display? Pre-arrival communication has the potential to reduce or even suspend uncertainty by making the conditions of resettlement knowable in advance of arrival.

Second, in most instances, digital communications via Facebook, Skype, and Whatsapp facilitate pre-arrival contact and provide the pre-arrival reception context of many sponsorsponsored interactions. A useful cue can be taken from knowledge management scholars who conceptualize information and communication technologies (ICT) as collaborative tools that underpin online communities. Trust figures prominently in the literature on ICT communities, especially regarding the important difference between information and knowledge. ${ }^{23}$ Sharratt and Usoro explain: "Both information and knowledge are grounded on data. The two can be differentiated if we consider interpretation and meaning. Information by definition is informative and, therefore, tells us something. It is data from which we can derive meaning. Knowledge is directly related to understanding and is gained through the interpretation of information. Knowledge enables us to interpret information, i.e., derive meaning from data. The interpretation of meaning is framed by the perceiver's knowledge. So what one person perceives as information can equate to meaningless data to another." ${ }^{24}$

In the co-created pre-arrival digital space, resettlement information is interpreted and made meaningful by both hosts and sponsored. Information becomes knowledge when it is deemed of direct relevance to the parties engaged in communicative exchange. Resettlement information is readily available, but any given piece of information may have little connection to the realities of resettlement. Consider the 2015 and 2016 media broadcasts of Prime Minister Trudeau welcoming refugees at Toronto's Pearson Airport, with gifts of winter clothing. ${ }^{25}$ This is an example of resettlement information, accessed and then interpreted by viewers. But it is not resettlement knowledge derived from the mutual recognition of needs exchanged between sponsors and sponsors. By contrast, pre-arrival sponsor-sponsored exchanges conducted via social media have the potential to translate resettlement information into resettlement knowledge assets, reducing uncertainty by bridging the gap between interpretation and expectation, and the actual conditions encountered in the resettlement context. Anyone expecting Justin Trudeau to greet them at Pearson Airport is likely to be disappointed.

Third, pre-arrival communication conducted in a cocreated digital space potentially breaks through the condition of refugeeness. As we have demonstrated elsewhere, ${ }^{26}$ paternalistic approaches by sponsors are often a consequence of a latent orientalism- "the sponsored" are defined as objects to be rescued-laying the groundwork for future conflict between sponsors and sponsored. In some cases, the sponsor-sponsored relationship breaks down completely. As Malkki notes, the "refugee" label often connotes the absence of sociocultural history. ${ }^{27}$ Processes and practices of reception and resettlement can homogenize persons whose individual hopes, fears, aspirations, and resignations are shaped through different ethnic, cultural, religious, class, gender, sexuality, and familial affiliations. Pre-conflict identities are not erased by the experience of war, persecution, and displacement; they are integral to how such experiences are negotiated, contested, accepted, and lived every day. ${ }^{28}$ Nor are experiences of third-country resettlement automatically determined by the definitional forces of host-reception. ${ }^{29}$

We have already written about how sponsored persons aspire to move beyond "refugeeness," to confirm their eligibility to exist and authority to act in pursuit of a life beyond refuge. $3^{30}$ But in analyzing the pre-arrival context delimited by "refugee-host" interaction we must go beyond what is 
permitted by identity-based approaches to resettlement. In social identity approaches to trust, scholars focus on groupbased stereotypes or in-group favouring behaviours based on salient group memberships. ${ }^{31}$ Trusted interactions with strangers, or out-group members, are generally thought to be weaker. However, in the case of the conflict-induced dispersal referred to as "the Syrian refugee crisis," a population of gendered and classed, rural-urban, Sunni and Shia Muslims, Assyrian Christians, Catholics, Greek Orthodox, Druze, Kurds, Turkmen, atheists and secularists, often pitted against each other, do not reformulate as a socio-culturally constituted "Syrian refugee group" on resettlement.

A limitation arises if a single group identity is assumed for all Syrian refugees and another is assumed for all hosts. Just as there is no single refugee voice or experience but voices and experiences of refugees, there is no single host voice or experience. ${ }^{32}$ Consequently, communication-based trusted contact does not fit neatly with acculturation, cross-cultural adaptation, or coordinated management of meaning approaches, 33 where trust is assumed to be a condition of interacting socioculturally constituted in-groups versus out-groups. While socio-cultural factors must be considered in any analysis sensitive to the condition of refugeeness, they cannot be the starting point for understanding how trusted relationships emerge between those defined as refugees and those defined as hosts.

In this article we demonstrate that, through digitally mediated, pre-arrival, trusted exchanges in co-created "third spaces of refugee resettlement," sponsored and sponsors transform resettlement information into "resettlement knowledge assets." These interactions not only facilitate the choice-centred, pre-settlement sharing of information, but also build trust between sponsored and sponsors and enhance the subjective experience (and reporting) of resettlement success.

\section{Data and Methods}

The data for this article are drawn from two studies on the PSRP. The first study examined the multi-perspectival nature of "resettlement success" in the rural reception context of Northumberland County, Ontario. Partnering with the Office of the Federal Member of Parliament and of the Director of Northumberland's Department of Economic Development, Land Use Planning and Tourism to facilitate introductions to the local sponsorship community, we interviewed 109 participants between December 2016 and March 2017. The sample included thirteen one-to-one interviews with representatives from public sector agencies; thirteen focus group interviews with private sponsor groups ( $N=47$ individuals); and in-depth interviews with forty-nine private sponsored refugees during their first twelve months of resettlement.

Our data collection and analysis followed a grounded theory approach, with the research team comparing data, refining concepts, and discussing theoretical implications throughout the study. A grounded theory approach-involving analytic inductive, deductive, and abductive modes of reasoning about empirical instances, cases, and the connections thereof (Charmaz 2014; Glaser and Strauss 1967; Timmermans and Tavory 2012) - is well suited for not only discovering novel social processes and patterns, but alsowhen and where the emerging data fit-integrating, extending, and revising existing theory and research. While the orientalism thesis and broader forced migration literature served as an analytical reference point in approaching the research setting, the analytical focus of the data collection and analysis was on the under-studied and under-theorized phenomenon of "resettlement success"; specifically, we focused on when and how sponsors and sponsored tended to experience resettlement in positive terms. A significant finding of the first study was that "resettlement success," as defined by the participants, was often tied to the quality of sponsor-sponsored pre-arrival contact.

In the second study, we pursued this analytical lead in a more focused and detailed way, identifying specific instances, types, processes, and patterns of pre-arrival contact in urban resettlement. We partnered with two Ontario-based NGOSthe Al-Qazzaz Foundation for Education and Development and the Syrian Canadian Foundation-to facilitate interviews with sponsors and sponsored refugees in the Greater Toronto Area. Between January and March 2018 we interviewed ninety-five participants from private sponsor groups $(N=45)$ and privately sponsored Syrian refugees $(N=50)$. Drawing on the insights of the first study and referencing the trust, refuge, and communication literatures, our data collection and analysis followed a semi-structured, in-depth interview approach, focusing on sponsor-sponsored, prearrival contact experiences and perspectives.

All private sponsor group and public agency interviews were conducted in English. All refugee interviews were conducted in Arabic. Consent forms and research descriptions were provided in both Arabic and English as appropriate. All interviews were voice-recorded and transcribed. All names used in this article are pseudonyms.

In what follows, we draw on the private sponsor group and refugee data from both studies to illustrate how digitally supported, pre-arrival contact between sponsor and sponsored contributed to and enhanced refugees' resettlement experiences. We conclude by discussing the implications of our findings.

\section{The Pre-Arrival Reception Context}

"We love this city and we do not want to go away from our sponsors, as we consider them like family." 
"The sponsor does not know our needs. I did not expect that my sponsorship program would be so bad. If I knew that in advance, I would have preferred to stay in Lebanon. I will not advise anyone to come here."

These contrasting responses from two privately sponsored refugees-the first from someone who had experienced prearrival digitally mediated contact with sponsors, the second from someone who did not-capture the polarity that emerged in our two studies. Both respondents quoted above were resettled in the same geographical area in Ontario. Both experienced and interpreted successful resettlement in ways that link their resettlement outcomes to their relationships and experiences with sponsors. In both cases, an understanding of what constituted their resettlement "needs" was underpinned by the level of interpersonal trust that had developed between them and their sponsors, and by the extent to which their expectations were congruent with those of their sponsors. We found examples of the same polarized outcomes in both studies, confirming that the congruence of sponsored-sponsor expectations was affected by the quality of trust obtained and the type of resettlement knowledge developed in advance of arrival. Elsewhere we more fully explore the nature and dynamic of sponsor-sponsored interpersonal trust after arrival. 34 Here we focus on the role of "third space interactions" in the dynamics of pre-arrival (mis)trust building, on the role played by pre-settlement digital contact in the acquisition of resettlement knowledge assets, and on subsequent reporting about resettlement success (or lack of success).

\section{Resettlement (Mis)information}

The majority of refugees in both studies had been exposed to four sources of information about Canadian resettlement: (1) media representations of resettlement, (2) online resettlement "facts", which sometimes overlapped with (3) diasporic resettlement rumour, and (4) Canadian government prearrival orientation sessions. Those who had not experienced significant pre-arrival contact with their sponsors arrived with resettlement expectations (as informed by these four sources of information) that often went unmet after arrival. This heightened rather than reduced resettlement uncertainty and negatively affected the already precarious experience of resettlement.

One interviewee who had no contact with his sponsors prior to arriving in Canada illustrated how his resettlement expectations were influenced by global media representations:

When we came to Canada, we were supposed to live a life of leisure until we get the citizenship, so we feel in harmony with the society.
It was supposed that the prime minister would receive us at the airport, or that he would come to visit the refugees to assure himself of their condition. No one from the government visits us and we cannot communicate with them.

His expectations (fuelled by media reports of the prime minister greeting Syrian refugees at Pearson Airport in Toronto) went unchallenged and thus were unmet. He was bitterly disappointed, and his social and institutional mistrust increased.

For others who hadn't experienced any sustained prearrival contact with their sponsors, expectations about what they would find in Canada were a product of diasporic rumour:

In Lebanon, forty families received approval to travel to Canada. Some of them who travelled before us contacted us and told us that their situation is much better. All of them told me that their homes are beautiful with new furniture. Except me, my situation is very bad and the furniture is shameful. The laid carpet would not be laid in refugee camps in Lebanon. The computer they brought was not good and broke down.

This respondent's expectations of what awaited him in Canada were not out of proportion to the life he and his family had enjoyed prior to the conflict. But with diasporic rumours as his only source of information, his aspiration to attain a life beyond refuge had become conflated with the (false) expectation that his pre-conflict status and role as breadwinner and father, and the material goods his family had enjoyed, would be attainable on resettlement.

Diasporic rumours about what to expect in Canada also could be negative:

Saher: I read about it on the internet. I would check the Facebook pages for information about resettlement. They would write that the Western governments will take our children and that if you go to such countries you will be forced to leave your faith. They wrote such things to scare people.

Institutional and social mistrust among refugees who went without pre-arrival contact with sponsors was further fuelled by false information, which keyed into fears related to threatened sociocultural history (faith) and social roles (parent-child). This kind of misinformation was effectively countered through sponsor-sponsored, pre-arrival contact:

Zina: [Pre-arrival, social media contact with sponsors] was useful, provided relief, and helped me feel less worried. I knew that there were people waiting for me, ready to help. I trusted them. People in Amman told me that we will be living in camps here in Canada, but 
I told them that I have people who will prepare a house for me. I trusted them, but I was afraid of bad luck.

The development of a trusted relationship with sponsors, achieved over time via regular interactions in co-created digital spaces reduced anxiety by rendering knowable what was previously unknowable. And while uncertainty remained, as Zina's interview attests, trusted contact was enough to counter misinformation spread by rumour. Key to trust-building were social-media-facilitated conversations with sponsors during which pre-conflict social roles, such as parent, father, and breadwinner were explicitly recognized and affirmed.

Bashir: Yes, it made me feel relieved every time. I knew that everything was prepared and that they would support us. I told my friends that there was someone in Canada who prepared a house for me and will help put my children in school.

The recognition of pre-conflict social roles helped to establish communication that went beyond language barriers.

Rasha: We felt more confident as he talked to us. Some people told us that we will be shocked as soon as we arrive. They said you won't be able to communicate with others, but as the sponsor talked to us we trusted him, and we felt it will be oK.

While socio-cultural histories have an influence on how resettlement is interpreted and negotiated, recognition of pre-conflict social roles such as "parent-child," "home maker," "breadwinner," and the material resources sustained through these roles created a bridge between conflict loss and the aspiration to attain a life beyond refuge. Central to trusted sponsor-sponsored contact was the co-creation of a shared interpretative framework through which resettlement information that addressed the concerns of refugees could become a resettlement knowledge asset, reduce uncertainty, and provide a mutual understanding of realistic resettlement expectations. This has significant implications when we consider an important means through which institutional trust could be built: government pre-arrival orientation programs.

\section{(Mis)trusted Contact}

Since 1998 the government of Canada has offered Canadian Orientation Abroad pre-arrival orientation sessions to help newcomers adapt to life in Canada by providing skills and information about what to expect upon arrival. Research has provided a mixed review of pre-arrival orientation sessions. ${ }^{35}$ Our findings indicate that limitations of the sessions are not related to the veracity of the information they provide. Some respondents, for example, were satisfied:
Fayrouz: It was an introductory seminar on Canada, its laws, how to live there, its weather and nationalities that live there. It contained a lot of information and they even explained to us about the air travel and how many kilos we are allowed to carry. All of us attended the seminar, including my younger child (ten years old). It was very useful for us.

However, the majority of our respondents were left with the impression that the information offered was patronising, paternalistic, and premised on a one-sided understanding of resettlement from the host perspective. As one couple told us,

Um Halil: The information we obtained was that we should not expect that we are going to paradise. That the air we breathe there costs money, and that life in Canada is not easy and we must work to be able to live.

Abu Halil: The course was not useful because they did not give us any information that would help us to survive. In my opinion, the course aimed to make the refugee understand that we should not be a burden on the Canadian government and we should work hard to be able to survive.

Institutional mistrust increased, as did uncertainty, and so information made available in pre-arrival institutional reception did not translate into knowledge assets that could facilitate realistic expectations of resettlement. Institutional mistrust increased when resettlement information was interpreted as biased by cultural status beliefs, which undermined attendees' pre-conflict sociocultural history and social roles:

Saher: They gave us a brief background about Canada and they told us not to hit our children when we arrive in Canada. We have left Syria and the war to be able to raise our children in a better way, not to hit them. There are a thousand ways that you can raise a child without hitting, but this is their idea about the Middle East. They think that the women and the children are hit and oppressed. But our religion keeps us from doing so.

By contrast, for those who developed pre-arrival trusted contact with sponsors, resettlement mistrust was reduced:

Lana: For us, if we didn't have those calls with our sponsors, we wouldn't have come to Canada. When they talked to us, we started to accept the idea of moving to Canada.

The perceived threat of sociocultural alienation de-escalated:

Samira: I didn't want to come to Canada. I didn't want to leave the Arab countries and come here to live among the foreigners. The sponsor's calls made me feel comfortable to come. 
We have laid out the pre-arrival terrain of resettlement information in order to demonstrate that imparting information, whether factually correct or not, can increase resettlement uncertainty. Information in and of itself cannot be thought of as an asset to inclusive resettlement. But, as our studies also show, resettlement information can be transformed into resettlement knowledge assets in the pre-arrival sponsor-sponsored relation of trusted contact.

\section{Resettlement Knowledge Assets and the Third Space of Refugee Reception}

It is important to note that there are instances in which pre-arrival sponsor-sponsored contact does not result in a common interpretative framework through which resettlement uncertainty can be sufficiently reduced. This occurred when pre-settlement engagement was premised solely on the exchange of impersonal information about the status of the sponsored's resettlement application. As one couple and their son told us,

Um Fuad: We received a phone call from the sponsor who said that our application was approved, and we should start preparing ourselves to travel to Canada. She kept calling me all the time to inform me about the progress of our application and the travel arrangements.

While contact was appreciated, procedural-based communication, even when frequent, did not establish a trusted relationship:

Abu Fuad: It would have been better if we got to know the sponsors pre-arrival. It would have given us the feeling of security. Having a relation with the sponsors before arrival would have helped us to feel more confident about our decision to go to a country we don't know anything about and we don't speak their language.

Um Fuad: It's not about getting information from the sponsors, it's about building a friendly relation with the people who will support us.

Their insights were confirmed by sponsor groups:

Alison: They [the refugees we were sponsoring] told me on Skype that they were living and surviving in that extreme and dangerous situation because they knew that there were people on this side of the world in Canada who love them. That made a whole difference in their lives. I think the communication is important, not only for the matter of filling out the paperwork, but also through Skype to talk to them and be their friend, be their listener and support. That helped them to keep on going through the one year almost of waiting for their application to be approved.
Pre-arrival sponsor-sponsored contact in and of itself is not experienced as a knowledge asset for either party. Resettlement information becomes a resettlement knowledge asset when trust grows and uncertainty is reduced empathically. The reflections of some sponsors provide further insight into the relationship between trusted contact and the reduction of uncertainty.

Gerard: Through Whatsapp texting and voice we called [the father] and started talking to him, trying to give him an idea of what to expect. It was challenging because they were really scared. They had no clue what was going on, like who are these people and why are they doing this? Why would anyone do this? So there was a lot of conversation between us. We tried to paint a picture of what is actually happening here, like, we are getting an apartment for you guys. It was really tough for them to grasp that level of participation from everyone, the cooperation and willingness to take them in as family.

For this sponsor group, the resettlement expectations of the sponsored were formed through reassurance and trustbuilding communications that reduced the unknown. By imparting information about sponsorship activities (such as the preparation of housing), concerns about significant elements of pre-conflict life that had been lost were mitigated. Through the sponsors' recognition of the challenges of displacement loss, resettlement fears were reduced. There was cooperation in support of resettlement between people who had never met. Other sponsor groups' experiences illustrate how interpersonal trust, social trust, and institutional trust developed through pre-arrival contact.

Alice: They really didn't know what they were signing up for. They went through all of the interviews and just thought they were going to come whenever... I think it is natural for it to take time to build trust, right? These are strangers who are bringing us to a strange country, different language, so there was a lot of building of trust. We explained basically who the group was, what we are doing as a group, what the government is doing, so we explained the entire system on several occasions.

From the perspective of sponsors, pre-arrival contact enabled them to develop a better understanding of how their expectations and those of the sponsored could influence and be influenced by incongruent perspectives. Insights developed before arrival became assets during resettlement.

Janice: There is sometimes a lack of understanding from each other's perspectives. For example, the experience of finding their new home or encouraging them to get a new job. From the sponsors' side, we've been in Canada for twenty years or fifteen years and we know how challenging the job market is. So when we were 
communicating, I needed to adjust how I conveyed this. They just came out of three years or longer of disastrous environment with no hope whatsoever for their lives, future, or dreams. Now they are in a new country, we can't just go and tell them, "No, it is a depressing job market. Canada will be harder to live in." Emotionally they weren't ready for that.

Familiarity, established through pre-arrival contact, merged with the practical matters of everyday life; seemingly insignificant gestures keyed into "normal" needs, the unquestioned activities of pre-conflict life:

Andrew: Each person involved in the sponsorship submitted a photo. Here's a photo of us. Here's what you're coming to, our family history, two boys, this and that, what do we like to do. So we sort of did those once every week or two so that there was some content going out, work it like a blog with content going out. They did the same for us. The father has an incredible backstory, which he sent over Whatsapp before they got here. Then as things went on, our communication went to more logistical things, you know, what's your shoe size and clothing size, so that as we collected things within the community for them, we knew what would work. So it became a very functional kind of thing.

Through trusted contact facilitated by digital communications, sponsors and sponsored engaged and developed trust, and the resettlement knowledge assets that resulted. The prearrival space in which they interacted is not determined by the context of displacement or that of resettlement. Rather, it is a neutral space in which the resettlement needs of the sponsored and those of their sponsors could achieve greater congruence. Sponsors and sponsored co-create a third space of refugee reception. This was confirmed by refugees:

Fayez: There was one sponsor in particular, she supported me, every single day when I was in Turkey. She knew how stressful it was and she supported me every day. I actually don't consider them sponsors, they are my friends. When I came they gave me so many books, because they know I lost my entire library when I left Syria.

Familiarity, trust, and knowledge created in this third space of refuge prepared the terrain for sponsorship actions that connected pre-conflict histories with post-refuge resettlement. Choice, discerned through sponsor/sponsored interactions in this third space, was significant in that it supported deliberative actions and agency:

Yasser: They were very nice to us. Gloria was the leader of the group and she is the one who was contacting us. She gave us the option to choose. She said they could either find a house for us or we would stay twenty days in Toronto in a temporary and choose the house we like and the area we would prefer to live in.

Refugees gave estimates of how frequent pre-arrival contact should be, providing insights into the effect it had on their resettlement experience. During the sponsorship application stage, hosts are generally in the position of selecting whom they sponsor. They have access to biographical and some demographic information about the sponsored. The same is not true for those being sponsored. But, as one respondent explained, the potential for a power imbalance, where hosts are accorded a greater sense of control over resettlement, can be countered by the reciprocal exchange of "refugee-host" information, which builds trust:

Saher: At least once per week. Every week we could have a thirtyminute chat, and this would help me understand how the life is here and if I will be able to live here or not. The sponsors know a lot about us; we should also be able to know about them too, to be prepared.

As trusted contact built, resettlement information exchanges became resettlement knowledge assets, with an impact on "lost time," a major effect of displacement. As trust developed, information became knowledge, providing continuity during long pre-arrival wait periods and helping to make up for lost time after arrival:

Yara: If possible, two or three times a month. This would at least build a relationship between the sponsors and the refugees. Through the phone calls or the video calls, a relationship will start. I personally prefer video calls. This relationship will make them comfortable, and although this might not seem that important at that time, it helps a lot and saves hours and days afterwards during the sponsorship process. It gives them the trust they need. The refugees are in a miserable state and they need this type of trust and support.

The resettlement effects of trusted pre-arrival contact, where information exchange is premised on mutual recognition, also became knowledge assets for sponsors, merging before and after reception, and creating online a third space of reception that was time sensitive:

Rex: It was just a whole level of comfort with them... I would go as far as saying that if we didn't have that earlier communication over the long wait time, then we would have started to consider this a dead program in our lives and that we were not even engaged with anything.

Alfred: We all arrived at the airport. A few of us came back to the apartment to show them around. I remember that night [the 
husband] sitting down in the chair and talking with us, "I'm just curious, where do we go from here because I already feel like you're family." We would not have had that connection if it was not for the earlier communication. Without that, we would have been starting from scratch.

Pre-arrival trusted contact was co-created in the digital third space of refugee reception, not limited to the temporal and spatial boundaries of displacement or resettlement. In the building of resettlement knowledge assets, neither party is rendered dependent on the other; rather, their respective needs merge to form "community-like" solidarities forged through the reduction of resettlement uncertainty. Unknowable future outcomes are made more knowable.

\section{Discussion}

In this article, we developed an understanding of the resettlement benefits of pre-arrival contact, by exploring what we conceptualize as resettlement knowledge assets and third-space resettlement contexts. Those who had engaged in digitally facilitated pre-arrival contact were able to mutually reduce the uncertainty of resettlement. The reduction of uncertainty was established in two senses related to trust building. First, sponsors keyed into the experience of precarity during displacement. They were made sensitive to experience in which the pre-conflict social roles of the displaced had assumed significance in providing a sense of continuity between what had been lost and what they aspired to regain post-conflict. Second, by engaging one-to-one pre-arrival, sponsors and sponsored orientated the exchange of resettlement information towards a recognition of needs that corresponded with their respective social roles. The sponsored could be recognized in their pre-conflict social roles as parents, spouses, and heads of family, while sponsors appeared in the roles they normally occupied in their daily lives. Information exchange premised on mutual need recognition was transformed into resettlement knowledge. The reduction of uncertainty through trust building modified the resettlement expectations of both sponsors and sponsored to the extent that resettlement knowledge became an asset after arrival.

The data included in this article pertain only to sponsorship participants, previously strangers to each other, some of whom engaged spontaneously in direct, digitally mediated, pre-arrival contact. There were other instances in which prearrival contact was facilitated indirectly by a Canada-based family member who was known to, but not part of, the sponsor group. And there were instances in which some sponsor group members were extended family members or acquaintances of the sponsored refugees. In such cases, resettlement knowledge assets did not always develop. Further research is required in order to better understand why this was the case. In all cases, longitudinal research would help to chart the relationship between resettlement knowledge assets and social, cultural, economic, and other well-being indicators during and after the first twelve months of resettlement.

All pre-arrival contact experiences detailed here are post-arrival recollections recorded with the benefit of hindsight. This can give the impression that pre-arrival contact was planned. In the majority of cases, pre-arrival contact occurred out of necessity and was not pre-meditated by sponsors or sponsored. This becomes more relevant when we consider the responses (developed in this article only by contrast) of sponsors and sponsored who did not have the opportunity to engage in pre-arrival contact, and whom we asked to gauge the extent to which they felt doing so would have been beneficial. Their responses could easily be the subject of an additional article. All of the sponsored refugees who had not experienced pre-arrival contact felt they would have benefitted, but when asked to imagine why this would be, tended to envisage the opportunity to ask procedural questions about the status of their applications. In the absence of trusted contact they could not imagine nor see the relevance of trust. Similarly, some sponsor group members who had not engaged in pre-arrival contact felt it would be useful to keep refugees apprised of the status of their applications. Others felt that pre-arrival contact could run the risk of placing refugees in a position of emotional dependency, and that contact should be limited to matters of procedural information-exchange. In the absence of trusted contact they could not envisage how establishing mutual reliance has beneficial effects on the unknowable future outcomes of resettlement. To those who had not co-created a third space of reception, resettlement knowledge assets were elusive.

\section{Notes}

1 Karen S. Cook, ed., Trust in Society (New York: Russell Sage Foundation, 2003); Francis Fukuyama, Trust: The Social Virtues and the Creation of Prosperity (New York: Free Press, 1995); Russell Hardin, Trust and Trustworthiness (New York: Russell Sage Foundation, 2002); Hardin, ed., Distrust (New York: Russell Sage Foundation, 2004); David J. Lewis and Andrew Weigert, "Trust as a Social Reality," Social Forces 63, no. 4 (1985): 967-85; Philip Pettit, “The Cunning of Trust," Philosophy \& Public Affairs 24, no. 3 (1995): 202-25.

2 Yann Algan and Pierre Cahuc, "Inherited Trust and Growth," American Economic Review 100, no. 5 (2010): 2060-92; Christian Bjørnskov, "How Does Social Trust Affect Economic Growth?" Southern Economic Journal 78, no. 4 (2012): 1346-68; Robert D. Putnam, Making Democracy Work: Civic Traditions in Modern Italy (Princeton, NJ: Princeton University Press, 1993); Guido Tabellini, 
"Institutions and Culture," Journal of the European Economics Association 6, no. 2-3 (2008): 255-94.

3 René Bekkers, "Trust and Volunteering: Selection or Causation? Evidence from a 4-Year Panel Study," Political Behavior 34, no. 2 (2012): 225-47; Luigi Guzio, Paola Sapienza, and Luigi Zingales, "Does Culture Affect Economic Outcomes?" Journal of Economic Perspectives 20, no. 2 (2006): 23-48.

4 John F. Helliwell and Shun Wang, "Trust and Wellbeing," International Journal of Wellbeing 1, no. 1 (2011): 42-78; Giuseppe Nicola Giurdano, Jonas Björk, and Martin Lindström, "Social Capital and Self-Rated Health: A Study of Temporal (Causal) Relationships," Social Science \& Medicine 75, no. 2 (2012): 340-8.

5 M. Lunje, "Inherited Trust and Economic Success of Second Generation Immigrants" (IFN working paper, 2012), cited in Yann Algan and Pierre Cahuc, "Trust, Growth, and Well-Being: New Evidence and Policy Implications," in Handbook of Economic Growth, vol. 2, ed. Philippe Aghion and Steven N. Durlauf, 49-120 (New York: Elsevier, 2014).

6 Eveliina Lyytinen, "Refugees' 'Journeys of Trust': Creating an Analytical Framework to Examine Refugees' Exilic Journeys with a Focus on Trust," Journal of Refugee Studies 30, no. 4 (2017): 489-510.

7 Behnam Behnia, "Trust Building from the Perspective of Survivors of War and Torture," Social Service Review 78, no. 1 (2004): 26-40.

8 Gaim Kibreab, "Pulling the Wool over the Eyes of the Strangers: Refugee Deceit and Trickery in Institutionalized Settings," Journal of Refugee Studies 17, no. 1 (2004): 1-26; Marjorie A. Muecke, "Trust, Abuse of Trust, and Mistrust among Cambodian Refugee Women: A Cultural Representation," in Mistrusting Refugees, ed. E. Valentine Daniel and John Chr. Knudsen, 36-55 (Berkeley: University of California Press, 1995).

9 Melanie Griffiths, "Vile Liars and Truth Distorters: Truth, Trust, and the Asylum System," Anthropology Today 28, no. 5 (2012): 8-12; Jennifer Hyndman, Managing Displacement: Refugees and the Politics of Humanitarianism (London: University of Minnesota Press, 200o); Hyndman, "Preventive, Palliative, or Punitive? Safe Spaces in Bosnia-Herzegovina, Somalia, and Sri Lanka," Journal of Refugee Studies 16, no. 2 (2003): 167-85; Tricia Hynes, "The Issue of 'Trust' or 'Mistrust' in Research with Refugees: Choices, Caveats and Considerations for Researchers," New Issues in Refugee Research, working paper no. 98, Evaluation and Policy Analysis Unit (Geneva: UNHCR, 2003); Eftihia Voutira and Barbara E. Harrell-Bond, "In Search of the Locus of Trust: The Social World of the Refugee Camp," in Daniel and Knudsen, Mistrusting Refugees, 207-24.

10 Daniel and Knudsen, Mistrusting Refugees; Ellen Lammers, "Community and Individual in the Aftermath of War: Perspectives from African Philosophy," Social Identities 11, no. 6 (2005): 607-29.
11 Marc Sommers, Fear in Bongoland: Burundi Refugees in Urban Tanzania (Oxford: Berghahn Books, 2001).

12 Ellen Lammers, "Community and Individual in the Aftermath of War: Perspectives from African Philosophy," Social Identities 11, no. 6 (2005): 607-29; Aldan Russell, "Home, Music and Memory for the Congolese in Kampala," Journal of Eastern African Studies 5, no. 2 (2011): 294-312.

13 Patricia Hynes, "Contemporary Compulsory Dispersal and the Absence of Space for the Restoration of Trust," Journal of Refugee Studies 22, no. 1 (2009): 97-121.

14 Hynes, "Contemporary Compulsory Dispersal and the Absence of Space," 100; see also Eftihia Voutira and Barbara E. Harrell-Bond, "In Search of the Locus of Trust: The Social World of the Refugee Camp," in Daniel and Knudsen, Mistrusting Refugees, 207-24.

15 Christopher Kyriakides, "Words Don't Come Easy: Al Jazeera’s Migrant-Refugee Distinction and the European Culture of (Mis)Trust," Current Sociology 65, no. 7 (2017): 933-52.

16 Michael P. Jasinski, Social Trust, Anarchy, and International Conflict (New York: Palgrave Macmillan, 2010).

17 Morton Beiser, "Sponsorship and Resettlement Success," Journal of International Migration and Integration 4, no. 2 (2003): 203-15; Beiser, "Resettling Refugees and Safeguarding Their Mental Health: Lessons Learned from the Canadian Refugee Resettlement Project," Transcultural Psychiatry 46, no. 4 (2009): 539-83; Thomas R. Denton, "Understanding Private Refugee Sponsorship in Manitoba," Journal of International Migration and Integration 4, no. 2 (2003): 257-71; Tracey M. Derwing and Marlene Mulder, "The Kosovar Sponsoring Experience in Northern Alberta," Journal of International Migration and Integration 4, no. 2 (2003): 217-36; Jennifer Hyndman, William Payne, and Shauna Jimenez, "The State of Private Refugee Sponsorship in Canada: Trends, Issues, and Impacts," policy brief submitted to the government of Canada, 2 December 2016 (Toronto: Centre for Refugee Studies, Refugee Research Network, York University, 2017); Michael Lanphier, "Sponsorship: Organizational, Sponsor, and Refugee Perspectives," Journal of International Migration and Integration 4, no. 2 (2003): 237-56; Robert A. Murdie, "Pathways to Housing: The Experiences of Sponsored Refugees and Refugee Claimants in Accessing Permanent Housing in Toronto," International Migration and Integration 9, no. 1 (2008): 81-101; Laura Simich, "Reinforcing Refugee Resettlement: An Introduction to Private Sponsorship and Partnerships," Journal of International Migration and Integration 4, no. 2 (2003): 153-6.

18 Yann Algan and Pierre Cahuc, "Trust, Growth, and WellBeing: New Evidence and Policy Implications," in Handbook of Economic Growth, vol. 2, ed. Philippe Aghion and Steven N. Durlauf, 49-120 (New York: Elsevier, 2014).

19 Guido Möllering, "The Nature of Trust: From Georg Simmel to a Theory of Expectation, Interpretation and Suspension," Sociology 35, no. 2 (2001): 403-20. 
20 Möllering, "Nature of Trust," 43.

21 Guido Möllering, “The Trust/Control Duality: An Integrative Perspective on Positive Expectations of Others," International Sociology 20, no. 3 (2005): 283-305.

22 Cindy Horst and Katarzyna Grabska, "Flight and Exile: Uncertainty in the Context of Conflict-Induced Displacement," Social Analysis 59, no. 1 (2015): 1-18.

23 Reem Talhouk, Syed Ishtiaque Ahmed, Volker Wulf, Clara Crivellaro, Vasilis Vlachokyriakos, and Patrick Olivier, "Refugees and HCI SIG: The Role of HCI in Responding to the Refugee Crisis," in Proceedings of the $2016 \mathrm{CHI}$ Conference Extended Abstracts on Human Factors in Computing Systems (New York: ACM, 2016), 1073-6; Ying Xu, Carleen Maitland, and Brian Tomaszewski, "Promoting Participatory Community Building in Refugee Camps with Mapping Technology," in Proceedings of the Seventh International Conference on Information and Communication Technologies and Development (New York: ACM, 2015), http://dx.doi. org/10.1145/2737856.2737883; Ling Zhao, Yaobin Lu, Bin Wang, Patrick Y.K. Chau, and Long Zhang, "Cultivating the Sense of Belonging and Motivating User Participation in Virtual Communities: A Social Capital Perspective," International Journal of Information Management 32, no. 6 (2012): 574-88.

24 Mark Sharratt and Abel Usoro, "Understanding Knowledge-Sharing in Online Communities of Practice," Electronic Journal on Knowledge Management 1, no. 2 (2003): 188.

25 Canadian Press, "Trudeau Greets Syrian Refugees with Coats in Toronto," 10 December 2015, CP24, https://www.cp24. $\mathrm{com} /$ news/trudeau-greets-syrian-refugees-with-coats-intoronto-1.2694713; Allison Jones, "We Came to Paradise': Syrian Refugees Arrive in Canada on Government Plane," CTV News, 11 December 2015, https://www.ctvnews.ca/canada/we-came-to-paradise-syrian-refugees-arrive-in-canada-on-government-plane-1.2696122; Andrea Janus, “I'm Proud to Be Here': Syrian Refugee Has Tearful Reunion with Justin Trudeau," Свс News, 5 December 2016, https://www. cbc.ca/news/canada/toronto/programs/metromorning/ metro-morning-justin-trudeau-refugee-reunion-1.3880485.

26 Christopher Kyriakides, Lubna Bajjali, Arthur McLuhan, and Karen Anderson "Beyond Refuge: Contested Orientalism and Persons of Self-Rescue," Canadian Ethnic Studies 50, no. 2 (2018): 59-78.

27 Liisa H. Malkki, "Speechless Emissaries: Refugees, Humanitarianism, and Dehistoricization," Cultural Anthropology 11, no. 3 (1996): 377-404.

28 Ruth M. Krulfeld, "Buddhism, Maintenance and Change: Reinterpreting Gender in a Lao Refugee Community," in Reconstructing Lives, Recapturing Meaning: Refugee Identity, Gender, and Culture, ed. Linda A. Camino and Ruth M. Krulfeld, 97-127 (New York: Gordon and Breach Publishers, 1994); Romola Sanyal, "Urbanizing Refuge: Interrogating Spaces of Displacement," International Journal of Urban and Regional Research 38, no. 2 (2014): 558-72;
Simon Turner, "What Is a Refugee Camp? Explorations of the Limits and Effects of the Camp," Journal of Refugee Studies 29, no. 2 (2016): 139-48; Mats Utas, "Victimcy, Girlfriending, Soldiering: Tactic Agency in a Young Woman's Social Navigation of the Liberian War Zone," Anthropological Quarterly 78, no. 2 (2005): 403-30.

29 Martha Kuwee Kumsa, “No! I'm Not a Refugee!' The Poetics of Be-longing among Young Oromos in Toronto," Refuge 19, no. 2 (2006): 230-55; Lalai Manjikian, "Refugee 'In-Betweenness': A Proactive Existence," Refuge 27, no. 1 (2010): 50-8.

30 Christopher Kyriakides, Arthur McLuhan, Karen Anderson, and Lubna Bajjali, "Status Eligibilities: The Eligibility to Exist and Authority to Act in Refugee-Host Relations," Social Forces 98, no. 1 (2019): 279-302.

31 Margaret Foddy and Robyn Dawes, "Group-Based Trust in Social Dilemmas," in New Issues and Paradigms in Research on Social Dilemmas, ed. Anders Biel, Daniel Eek, Tommy Gärling, and Mathias Gustafsson, 57-85 (New York: Springer, 2008); Michael J. Platow, Margaret Foddy, Toshio Yamagishi, Li Lim, and Aurore Chow, “Two Experimental Tests of Trust in In-Group Strangers: The Moderating Role of Common Knowledge of Group Membership," European Journal of Social Psychology 42, no. 1 (2012): 30-5; Martin Tanis and Tom Postmes, "A Social Identity Approach to Trust: Interpersonal Perception, Group Membership and Trusting Behaviour," European Journal of Social Psychology 35, no. (2005): 413-24.

32 Christopher Kyriakides, Arthur McLuhan, Karen Anderson, and Lubna Bajjali, "Status Eligibilities: The Eligibility to Exist and Authority to Act in Refugee-Host Relations," Social Forces 98, no. 1 (2019): 279-302.

33 Skye Jorden, Kimberly Matheson, and Hymie Anisman. "Supportive and Unsupportive Social Interactions in Relation to Cultural Adaptation and Psychological Distress among Somali Refugees Exposed to Collective or Personal Traumas," Journal of Cross-Cultural Psychology 40, no. 5 (2009): 853-74; Edith Montgomery, “Tortured Families: A Coordinated Management of Meaning Analysis," Family Process 43, no. 3 (2004): 349-71; Charles Okigbo, Jennifer Reierson, and Shelly Stowman, "Leveraging Acculturation through Action Research: A Case Study of Refugee and Immigrant Women in the United States," Action Research 7, no. 2 (2009): 127-42.

34 Kyriakides et al., "Beyond Refuge."

35 Jennifer Hyndman, "Research Summary on Resettled Refugee Integration in Canada" (United Nations High Commissioner for Refugees, 2011); Nicole Maine, "I'm the One Who iI Looking After My Family': Refugee Youth Brokers, Pre-Departure Orientation, and Settlement in Canada" (MA thesis, York University, 2015); Kathy Sherrell, Chris Friesen, Jennifer Hyndman, and Subrath Shrestha, From "One Nation, One People" to "Operation Swaagatem": Bhutanese Refugees in Coquitlam, BC (Vancouver: Metropolis British Columbia, 2011); Debra Pressé and Jessie Thomson, 
"The Resettlement Challenge: Integration of Refugees from Protracted Refugee Situations," Refuge 25, no. 1 (2008): 94-9.

Christopher Kyriakides holds the position of Canada Research Chair in Citizenship, Social Justice, and Ethno-Racialization at York University, Canada. He may be contacted at ckyriak@ yorku.ca.

Arthur McLuhan is a research fellow at York University and theory division chair of the Society for the Study of Social Problems. He may be contacted at mcluhan@yorku.ca.
Karen Anderson is an associate professor in the Department of Sociology, York University. She can be reached at karenand@ yorku.ca.

Lubna Bajjali is a research associate with the Department of Sociology, York University, Canada. She may be reached at l.bajjali@yorku.ca.

Noheir Elgendy is the executive director of Al-Qazzaz Foundation for Education and Development and adjunct professor at Ryerson University. She may be contacted at noheir@gmail .com. 